\title{
Prospects and social effects of carbon dioxide sequestration and utilization projects
}

\author{
Alina A. ILINOVA Natalya V. ROMASHEVA, Gennadiy A. STROYKOV \\ Saint Petersburg Mining University, Saint Petersburg, Russia
}

How to cite this article: Ilinova A.A., Romasheva N.V., Stroykov G.A. Prospects and social effects of carbon dioxide sequestration and utilization projects. Journal of Mining Institute. 2020. Vol. 244, p. 493-502. DOI: $10.31897 /$ PMI.2020.4.12

\begin{abstract}
The issues of global warming and occurrence of the greenhouse effect are widely discussed on a global scale. Various methods of reducing greenhouse gas emissions are actively being investigated and tested, including technologies for sequestration of carbon dioxide, the implementation of which is carried out in the form of CC(U)S (carbon capture, utilization and storage) projects related to capture, disposal and, in some cases, use of $\mathrm{CO}_{2}$. In Russia, $\mathrm{CC}(\mathrm{U}) \mathrm{S}$ technologies are not yet used, but there is a significant potential for their development and distribution. $\mathrm{CC}(\mathrm{U}) \mathrm{S}$ technologies acquire a special role in the context of the development of the energy and industrial sectors of Russia, which are key sources of emissions, and the geological objects belonging to them are potential carbon storages. The purpose of this study is to conceptually analyze the CC(U)S technological cycle and typify such projects, assess the prospects for their implementation in Russia, and identify social effects from the implementation of $\mathrm{CC}(\mathrm{U}) \mathrm{S}$ projects. The main results of the study are presented in the form of a typology of CC(U)S projects, a strategic analysis of the prospects for introduction of such technologies in Russia, as well as development of approaches to assessing social effects with systematization and highlighting a set of indicators for their assessment, which can serve as a basis for re-estimation of the values of $\mathrm{CC}(\mathrm{U}) \mathrm{S}$ projects. The main research methods used were methods of decomposition, systematization and typology, as well as strategic analysis with a focus on relevant practical materials on the topic of the work. Directions for further research are related to the substantiation of the methodology for assessing social effects of $\mathrm{CC}(\mathrm{U}) \mathrm{S}$ projects, including for the conditions of Russia, based on the principles of balancing the interests of key participants.
\end{abstract}

Key words: technology; sequestration; carbon dioxide; Russia; projects; SWOT analysis; social effects; CC(U)S

Acknowledgments. The study was supported by a grant from the Russian Science Foundation (project N 18-18-00210 "Development of a methodology for assessing the public effectiveness of carbon dioxide sequestration projects").

Introduction. The problem of climate warming was first raised in the 1980 s by the United Nations. In recent decades, initiatives aimed at reducing greenhouse gas emissions have been systematically implemented.

In 1988, under the auspices of the United Nations and the World Meteorological Organization (WMO), the Intergovernmental Panel on Climate Change (IPCC) was formed to assess the risk of such change caused by anthropogenic activity. In 1992, the United Nations Framework Convention on Climate Change (UNFCCC), embodying the general principles of action by countries on the problem of climate change, was adopted. In 2005, the Kyoto Protocol was ratified, and in 2015, the Paris Agreement, which regulates measures to reduce carbon dioxide in the atmosphere, was signed. The purpose of the agreement is containment of Earth's temperature rise within $1.5{ }^{\circ} \mathrm{C}$.

According to BP (BP Statistical Review of World Energy 2019), the amount of $\mathrm{CO}_{2}$ emissions in the world at the end of 2018 reached its maximum (33.9 billion tons) with an average growth about $1 \%$ per year in 2007-2017 [12]. Russia ranks fourth in the world in terms of emissions (1.55 billion tons in 2018 , i.e., $4.5 \%$ of the global amount) after China $(27.8 \%)$, the USA $(15.1 \%)$, and India (7.2\%) [12]. At the same time, the bulk of $\mathrm{CO}_{2}$ emissions in Russia falls onto the energy and industrial sectors, the share of which is about 79 and $11 \%$, respectively, along with agriculture (6\%) [4]. A significant amount of emissions in the energy sector in Russia is due to extraction, processing, transportation and further use of oil, natural gas, associated petroleum gas, coal, and peat. 
For example, according to the results of 2017, the total emissions of $\mathrm{CO}_{2}, \mathrm{CH}_{4}$ (methane), and $\mathrm{N}_{2} \mathrm{O}$ (nitrogen oxide) from oil operations exceeded the 1990 level by $5.4 \%$ and reached 37.8 million tons. Drilling, testing, and servicing of operating oil wells are the main sources of $\mathrm{CO}_{2}$ emissions and account for about $98.5 \%$ of total emissions from oil operations [4].

$\mathrm{CO}_{2}$ emissions from the industrial sector are associated with combustion of fossil fuels and include the production of electricity and heat for its own use; these are enterprises of ferrous and nonferrous metallurgy, as well as the chemical industry. Most of the emissions in metallurgy come from the smelting of iron and steel, followed by the production of primary aluminum; in the chemical industry, this is the production of ammonia [4].

Sequestration technologies are one of the ways to reduce $\mathrm{CO}_{2}$ emissions into the atmosphere and, as a result, reduce the greenhouse effect. In the literature, such technologies are also called $\mathrm{CO}_{2}$ capture and storage technologies or CCS (carbon capture and storage) technologies. The technological cycle comprises catching (capture, separation) of $\mathrm{CO}_{2}$ from sources (most often industrial) in order to prevent it from entering the atmosphere, preparation and subsequent transportation, as well as injection of carbon dioxide for long-term safe isolation under the ground. In some cases, the technological cycle may include the beneficial use of gas; then such technologies are called technologies for sequestration and utilization of $\mathrm{CO}_{2}$, i.e, CCUS (carbon capture, utilization and storage). The emergence of technologies capable of full use of $\mathrm{CO}_{2}$ without its subsequent disposal led to the emergence of CCU (carbon capture and utilization) projects. The authors of the article use the designation $\mathrm{CC}(\mathrm{U}) \mathrm{S}$ technologies and projects.

According to the Global CCS Institute, as of 2019, there are 43 large-scale CC(U)S projects in the world, 18 of which are in operation and the rest are at early stages of development. The leader in the number of active projects is North America (mainly the USA), in terms of the number of projects in the early stages - China and Europe*. The most widespread type of CC(U)S projects in the world are EOR- $\mathrm{CO}_{2}\left(\mathrm{CO}_{2}\right.$-enhanced oil recovery) projects aimed at increasing oil recovery; projects are also implemented in the coal, cement and gas industries, metallurgy, chemical and mining and chemical sectors [21].

$\mathrm{CC}(\mathrm{U}) \mathrm{S}$ projects in the world are at the initial stage of development; mainly, pilot versions are being implemented. The factors hindering their development were analyzed in studies published by the authors $[8,15,21]$ and are associated with economic and organizational and managerial aspects, safety, as well as the society's reaction to the long-term disposal of technogenic $\mathrm{CO}_{2}$ underground.

The development issues of $\mathrm{CC}(\mathrm{U}) \mathrm{S}$ technologies and projects are widely reflected in foreign publications in various contexts and are practically not considered by domestic scientists. Foreign scientists are exploring such aspects as the role of state support in the development of CC(U)S technologies and projects [11, 13, 25]; barriers to their development [28]; the roles, responsibilities and benefits of stakeholders [14], and much more. The publications are also devoted to the study and analysis of arguments "for" and "against" the CC(U)S projects [22].

Foreign publications are devoted to specific examples of $\mathrm{CC}(\mathrm{U}) \mathrm{S}$ clusters and projects development [23] and situations in specific countries [11, 30]. In some studies, the division of CC(U)S technologies into types is presented, but to a greater extent they are aimed at specific kinds [29].

Foreign scientific works are mainly analytical and descriptive, with much attention paid to practical aspects. In addition, the results of studies by foreign authors have specific features typical for concrete countries and situations, and can only be used as a guideline for the conditions of Russia.

In the Russian scientific literature, attention paid to the problem of greenhouse gas emissions and development of $\mathrm{CC}(\mathrm{U}) \mathrm{S}$ technologies, especially from the point of view of economics and management, is insufficient. Research of the scientists of Mining University is aimed on economy

\footnotetext{
${ }^{*}$ Hiroshi Nambo. Presentation of Global CCS Institute. CCS Knowledge Sharing Meeting between Global CCS Institute and St. Petersburg Mining University. Japan CCS Co. 2019. May, 23.
} 
of $\mathrm{CO}_{2}$ sequestration. Published articles are dedicated to stakeholder management in $\mathrm{CC}(\mathrm{U}) \mathrm{S}$ projects $[8,15]$, state regulation of the $\mathrm{CC}(\mathrm{U}) \mathrm{S}$ technologies development [21], assessing the potential of using EOR- $\mathrm{CO}_{2}$ technologies in the conditions of Russia [5, 19], re-evaluation of the economic value of carbon dioxide in the light of the circular economy concept [26], prospects and economic and social aspects of the technologies under consideration [6, 7, 12, 27], etc.

Formulation of the problem. Despite the sufficient number of foreign publications, and taking into account the limited number of those in Russia, the topic under consideration needs additional study.

The purpose of this study is to present a system of views on the development of CC(U)S projects, including that in the conditions of Russia, with a focus on their features, typology, in addition to the need to identify social effects from their implementation. To achieve this goal, a number of tasks were solved: the essence of $\mathrm{CC}(\mathrm{U}) \mathrm{S}$ projects was investigated and the typification of CC(U)S technologies was carried out; the prospects for the implementation of $\mathrm{CC}(\mathrm{U}) \mathrm{S}$ projects in the conditions of Russia were assessed; approaches to identifying the impact of $\mathrm{CC}(\mathrm{U}) \mathrm{S}$ projects on society have been identified.

The novelty of the research lies in the typology of various types of $\mathrm{CC}(\mathrm{U}) \mathrm{S}$ projects and development of a system of indicators that provides for assessing the effects of implementation of such projects on society.

Methodology. During the research, the authors analyzed more than 100 literary sources (mainly foreign) on various economic aspects of carbon dioxide sequestration, a significant part of which is presented in such authoritative publications as Energy Procedia, Energy Policy, Applied Energy, International Journal of Greenhouse Gas Control and others. Particular attention was paid to the materials presented in the analytical reports of such organizations and associations as the Global CCS Institute, World Energy Council, International Energy Agency (IEA), Carbon Capture and Storage Association, etc., as well as in specialized databases (CCS projects' databases), such as the National Energy Technology Laboratory (NETL), Carbon Capture and Sequestration Technologies Data Base at MIT, etc.

The main research method was desk research, along with comparative, logical-structural, situational, factorial, systemic, cause-and-effect analyzes, inductive and deductive approach, methods of decomposition, systematization, and typology, as well as SWOT analysis. When defining the essence of $\mathrm{CC}(\mathrm{U}) \mathrm{S}$ projects and identifying the stages of their development, the authors focused on the generally accepted theory of project management in terms of the structural model of the project by phases of the life cycle and decomposition of the project work [10]. To systematize the social effects of $\mathrm{CC}(\mathrm{U}) \mathrm{S}$ projects, the above-mentioned methods and approaches were used, as well as the method of grouping indicators by areas, and general methodological principles of economic analysis and assessment (consistency, complexity, dynamic and the principle of comparative analysis).

Research results. The essence and typology of $C C(U) S$ technologies and projects. To understand the essence of CCS projects, the work presents general stages of their development (Fig.1) with a description of the content of each stage (Table 1).

From the point of view of stages in CCUS projects, a stage of $\mathrm{CO}_{2}$ use is added with a detailed feasibility study, while the life cycle of CCU projects is a the cycle of a production project cycle not related to gas storage.

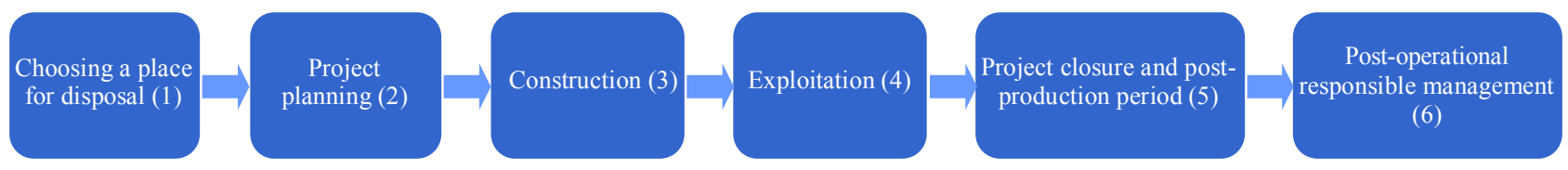

Fig.1. Stages of CCS projects development 
The essence of the stages of CCS projects development

\begin{tabular}{c|l}
\hline Stage & \multicolumn{1}{|c}{ Content } \\
\hline 1 & $\begin{array}{l}\text { Collection and analysis of initial data, preliminary study and justification of organizational, technical } \\
\text { and economic feasibility of the project, study of the characteristics of a potential storage facility, trial } \\
\text { injection } \\
\text { Development of a comprehensive project development plan, project risk assessment, development of a } \\
\text { contingency plan, analysis and assessment of key project stakeholders, justification of the economic } \\
\text { feasibility of the project }\end{array}$ \\
3 & $\begin{array}{l}\text { Construction and arrangement of the facility, development of (adaptation of the existing one) infra- } \\
\text { structure, trial commissioning, additional geological research, technology testing }\end{array}$ \\
4 & $\begin{array}{l}\mathrm{CO}_{2} \text { injection, constant ongoing monitoring and validation, permanent updating of the subsurface } \\
\text { model } \\
\text { Cessation of } \mathrm{CO}_{2} \text { injection, shutdown of on-site operations, wells abandonment, post-production mon- } \\
\text { itoring, project closure } \\
\text { Monitoring of the facility until the moment when it ceases to pose a threat, certification of closure, } \\
\text { transfer of responsibility for the facility, long-term monitoring }\end{array}$ \\
\hline
\end{tabular}

Duration, years

Figure 2 shows a diagram of a technological cycle with a simultaneous typology of CC(U)S technologies (the diagram was compiled by the authors using $[18,20]$ ).

CCS projects are related to capture and storage of carbon dioxide in geological formations and aquifers. An example of such a project is the carbon dioxide sequestration project Tomakomai CCS Project in Japan, a. When choosing geological structures for disposal, it is advisable to focus on the experience gained during the operation of gas and oil fields, in addition to creation of underground gas storage facilities [1]. For long-term storage of carbon dioxide, underground reservoirs can be

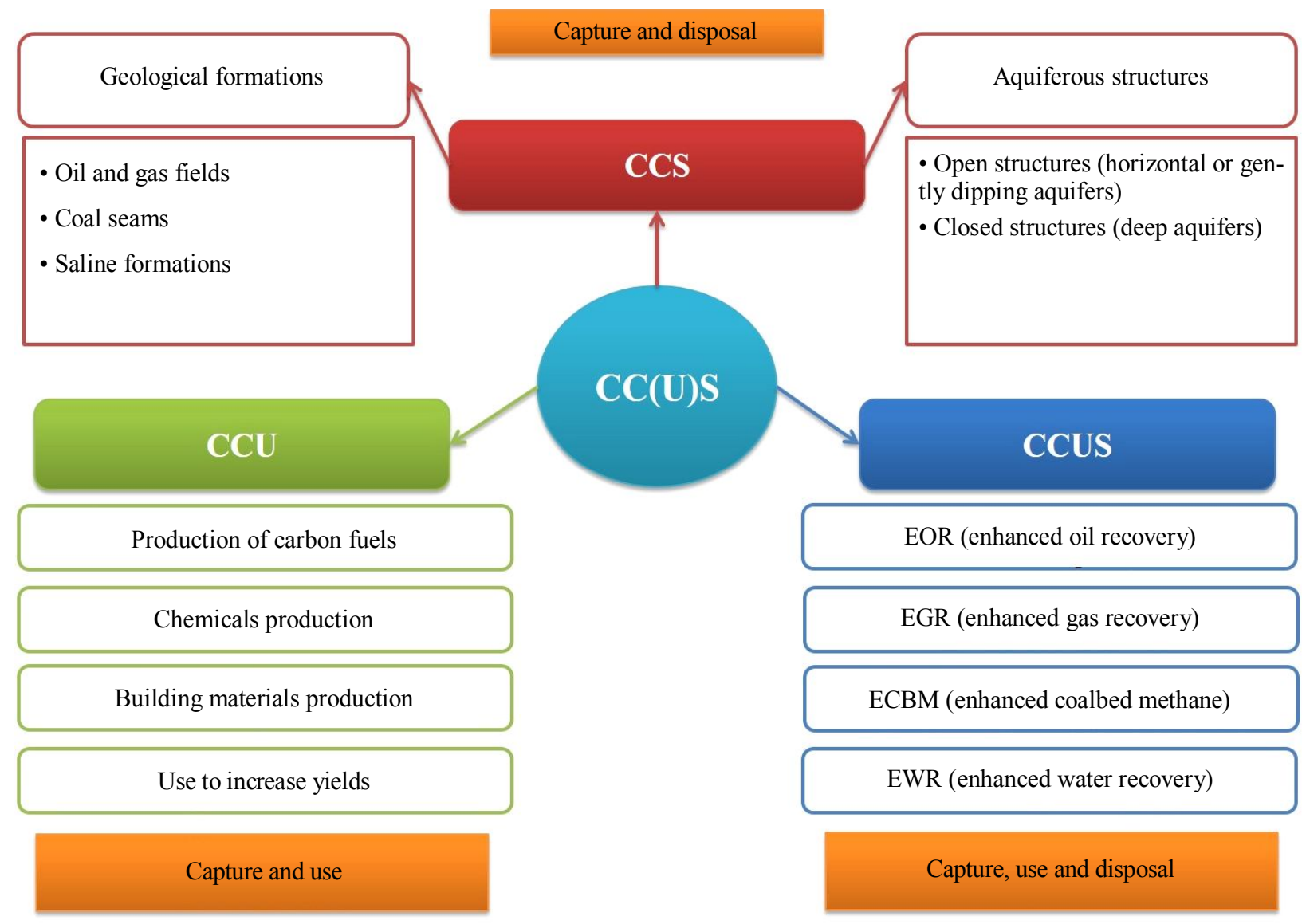

Fig.2. Typology of CC(U)S technologies 
used, i.e., spent and operating oil and gas fields, salt formations, and undeveloped coal seams. The latter use case provides additional opportunities for the accumulation and use of adsorbed methane. Thus, this physical process allows to achieve two goals: to solidify greenhouse $\mathrm{CO}_{2}$ and to release the $\mathrm{CH}_{4}$ net energy resource in the process of degassing the coal seam [1, 2, 24]. It is obvious that CCS technologies are not commercial. The main incentives for the use of projects are contributing to the global fight against $\mathrm{CO}_{2}$ emissions, creation of a demonstration facility, testing and development of technologies, improving the image of the state and project participants, etc. They reflect attitude of the country and business to the fight against global environmental problems.

The CCUS and $\mathrm{CCU}$ projects are associated with the use of $\mathrm{CO}_{2}$, while the former are also associated with its disposal. CCUS technologies are used mainly in extraction of minerals, specifically to enhance oil recovery; it is also possible to use them for extraction of liquid mineral resources and displacement of deep-lying saline water with its further restoration and use for industrial, agricultural or domestic purposes [18]. CCUS projects in the world are mainly represented by $\mathrm{CO}_{2}$-EOR projects (for example, the Weyburn-Midale Carbon Dioxide Project, Canada).

$\mathrm{CCU}$ projects are associated with the complete utilization of $\mathrm{CO}_{2}$, but such projects are more in the early stage of development around the world. Most of CCU technologies are implemented in the form of small pilot projects in various industries. According to the IEA report [20], four key areas of the carbon dioxide use have emerged (Fig.2). For example, several chemicals require carbon for their structure and properties, while carbonaceous fuels can become critical in cases where the use of electricity or hydrogen is limited (for example, in aviation). Such technologies are rightfully innovative and soon may take a significant place in various industries.

Prospects for the development of CC(U)S technologies in Russia. Today, no CC(U)S projects are being implemented in the Russian Federation; however, for many reasons, their implementation is promising and may lead to economic and significant social effects in the future. Figure 3 shows the main strengths and weaknesses, as well as opportunities and threats, for the development of $\mathrm{CC}(\mathrm{U}) \mathrm{S}$ technologies in Russia.

Leading experts predict that fossil fuels will play an important role in meeting Russia's energy needs in the coming decades. Further focusing on traditional energy sources will ensure the demand for environmental technologies, including $\mathrm{CC}(\mathrm{U}) \mathrm{S}$ technologies. $\mathrm{CC}(\mathrm{U}) \mathrm{S}$ projects are characterized by high capital and operating costs, which is the main barrier to their large-scale implementation; however, if implemented, additional volumes of oil, methane, liquid mineral resources obtained as a result of implementation of such projects make it possible to partially or fully compensate for the cost of capturing and transporting $\mathrm{CO}_{2}$, and in some cases, obtain a commercial effect.

A threat to the development of CC(U)S technologies in Russia is the existing environmental legislation, which is characterized by fairly low penalties for the companies' negative impact on the environment. The legislation is unchanging, which does not stimulate big business to actively introduce environmental technologies. At the same time, the development of alternative energy, the introduction of modern technologies for land reclamation, use of industrial waste, utilization of associated petroleum gas, etc., also hinder the development of $\mathrm{CC}(\mathrm{U}) \mathrm{S}$ technologies, since the budget allocated by companies for environmental projects is quite limited.

The immaturity of the technologies used raises a big question about the prospects for the $\mathrm{CC}(\mathrm{U}) \mathrm{S}$ projects, but a number of countries have already accumulated significant experience in their implementation. Pilot projects of CCUS projects were carried out in Russia too, in particular, in the fields in the Republic of Tatarstan, where $\mathrm{CO}_{2}$ was used to enhance oil recovery. During the first three years of the project implementation, pilot $\mathrm{CO}_{2}$ injection was successfully carried out at the Yelabuga field; however, in 1989 the project was shut down for financial reasons [5]. 


\section{Strengths}

- The presence of many aquifers, geological formations, underground reservoirs, including depleted oil fields for $\mathrm{CO}_{2}$ storage

- The presence of many technogenic sources of $\mathrm{CO}_{2}$

- Implementation of $\mathrm{CC}(\mathrm{U}) \mathrm{S}$ projects is possible on the basis of operating enterprises with well-developed infrastructure

\section{Opportunities}

- Achieving significant positive social effects, including job retention

- Further orientation of the country towards the use of traditional energy sources

- Application of tax incentives and tax credits for companies implementing $\mathrm{CC}(\mathrm{U}) \mathrm{S}$ projects

- Difficulties in applying $\mathrm{CO}_{2}$ emissions trading mechanism due to the lack of approved documents defining the procedures and rules for the application of this mechanism, which contributes to the introduction of environmental technologies

- Improving Russia's image abroad

- Desire of large industrial enterprises to implement the principles of sustainable development

\section{Weaknesses}

- Non-maturity of some stages of the capture - transportation disposal $-\mathrm{CO}_{2}$ use technological chain

- High initial capital and current operating costs for the implementation of $\mathrm{CC}(\mathrm{U}) \mathrm{S}$ projects

- Lack or low commercial efficiency of CC(U)S projects

- Lack of a regulatory framework conducive to the implementation of CC(U)S technologies

- Potential $\mathrm{CO}_{2}$ leaks from geological formations

\section{Threats}

- Volatility of prices for received products in case of implementation of CCUS and CCU projects

- Negative perception of projects by society

- Development of other environmental technologies

- Stability of environmental legislation not intended to tighten it up

- Limited opportunities for international cooperation due to existing sanctions

Fig.3. SWOT analysis of CC(U)S technologies development in Russia

There are many oil fields in Russia that are at a late stage of development, as well as technogenic sources of $\mathrm{CO}_{2}$ near depleted fields $[5,19]$, therefore CCUS $\left(\mathrm{EOR}-\mathrm{CO}_{2}\right)$ projects can be considered promising [3].

The development of $\mathrm{CC}(\mathrm{U}) \mathrm{S}$ projects may be threatened by public concerns associated with the possibility of leaks of buried $\mathrm{CO}_{2}$; however, the available world experience in the implementation of $\mathrm{CC}(\mathrm{U}) \mathrm{S}$ projects demonstrates that in the case of careful monitoring of $\mathrm{CO}_{2}$ behavior underground and availability of a well-functioning system responding to possible leaks, underground storage of $\mathrm{CO}_{2}$ can be quite safe. Despite the absence or low commercial efficiency of CC(U)S projects, their implementation can lead to positive social effects.

Thus, we can state that there are prospects for the implementation of CC(U)S technologies in Russia. The prospects are conditioned by the existence of a large number of aquifers, geological formations, underground reservoirs, including oil and gas fields with a high degree of depletion; the desire of industrial enterprises to conform to the image of environmentally-oriented, as well as possible social effects. Nevertheless, a number of limitations do not allow for large-scale implementation of these technologies in the short term; however, the positive consequences of their implementation make their implementation introduction attractive in the future. 
The system of social effects of $\mathrm{CC}(\mathrm{U}) \mathrm{S}$ technologies and projects development

\begin{tabular}{c|c|c|c}
\hline Society and economy & Safety and health & Environment & Long-term environmental development \\
\hline
\end{tabular}

The essence

Social effect and social and economic consequences for individuals and society as a whole, including the development of territories
Environmental impact and potential impact on public health

Environmental effect and
potential impact on the
environment (atmosphere,
soil, water and ecosystem
in general)

Environmental effect and environment (atmosphere, soil, water and ecosystem in general)
Strategic effect of environmental technologies development and scaling up and formation of consciousness building, reflecting the environmental aspect of the relationship between man and the environment
Positive influence

Development and maintenance of the infrastructure; economic development of the territory; training at all stages of human life; creation of new and preservation of existing jobs; influx of various groups of people to the sites (educational tours, scientific research, tourism); development of scientific potential
Improvement of the general environmental situation in the region; positive impact on human health; improving the well-being of people
Reduction of emissions, contribution to the fight against global warming; adherence to the principles of sustainable development; status of a region with a favorable environmental situation (image component)
Development and diffusion of environmentally oriented technologies $\mathrm{CC}(\mathrm{U}) \mathrm{S}$; new business opportunities based on sustainable development principles; promotion of environmental principles and formation of environmental human consciousness (public and individual)
Negative influence

Negative impact on economic activities of local residents (farming, agriculture, fishing); seizure of land for the needs of the project; possible decrease in the value of land and real estate in areas near the project implementation site; use of taxpayers'; funds (through the mechanisms of state support for $\mathrm{CC}(\mathrm{U}) \mathrm{S}$ projects)
Detrimental effect on human health in case of leaks and accidents; possible impact of associated harmful gases (hydrogen sulfide), increased risk of seismic activity (not proved)
Possible leaks of carbonic acid gas and pollution of air, soil, surface and ground waters; change in biodiversity; seizure of land (including for agricultural purposes); increased risk of seismic activity (not proved)
Decrease in the rate of development of environmentally friendly technologies aimed at reducing carbon dioxide emissions; slowdown in the development of resource- and energy-efficient technologies; weakening incentives to reduce the use of fossil fuels
Maximization criteria

Number of new industrial facilities, pcs. Number of new infrastructure facilities for social and engineering purposes, pcs. Volume of social investments, monetary units

Number of new educational programs and courses (by education levels), pcs. Share of business and excursion tourism in the total volume of tourist flow, $\%$

Number of new related projects (for example, "smart farms" using $\mathrm{CO}_{2}$ as a plant growth stimulant), pcs.

Number of farms, pcs.

Land area for farming and agriculture, ha

The cost of land in the region, monetary units / ha

Real estate value in the region, monetary units $/ \mathrm{m}^{2}$
Level of people with good health, $\%$
Level of carbon dioxide concentration in soils, waters, $\%$

Species biodiversity, pcs.

Position of the region in the ranking of regions with a favorable ecological situation
Level of development of CC(U)S technologies (by stages of the technology cycle), score (expert evaluation)

Level of development of other environment-friendly technologies, score (expert evaluation)

Level of public awareness about CC(U)S technologies, \%

Level of environmentally conscious people, $\%$

Number of new technologies for the use of carbon dioxide, pcs.

Quantity of new products to be received, pcs.

Share of used carbon dioxide in the total amount of captured carbon dioxide, $\%$ 
The end of the table 2

\begin{tabular}{|c|c|c|c|}
\hline Society and economy & Safety and health & Environment & Long-term environmental development \\
\hline \multicolumn{4}{|c|}{ Minimization criteria } \\
\hline $\begin{array}{l}\text { Unemployment rate among the popula- } \\
\text { tion, \% } \\
\text { Land area for the needs of the project, } \\
\text { ha }\end{array}$ & $\begin{array}{l}\text { Sickness level in the } \\
\text { region, \% } \\
\\
\\
\text { Level of concentratiol } \\
\text { mosphere, ppm } \\
\text { Number of accidents } \\
\text { Concentration level o } \\
\text { the atmosphere, ppm } \\
\text { Number of cases of se } \\
\text { Number of environme } \\
\text { Level of severity of th } \\
\text { degree (from satisfact } \\
\text { Area of seized land, } \mathrm{h}\end{array}$ & $\begin{array}{l}\mathrm{CO}_{2} \text { emissions, billion } \\
\text { tons } \\
\text { carbon dioxide in the at- } \\
\text { s), pcs. } \\
\text { ociated harmful gases in } \\
\text { ic activity, pcs. } \\
\text { problems, pcs. } \\
\text { toironmental situation, } \\
\text { to catastrophic). }\end{array}$ & $\begin{array}{l}\text { Share of fossil fuels from all } \\
\text { sources, \% } \\
\text { Level of government (business) } \\
\text { expenditure on R\&D and develop- } \\
\text { ment CC(U)S, monetary units } \\
\text { Level of government (business) } \\
\text { expenditure on R\&D and develop- } \\
\text { ment of other environmental tech- } \\
\text { nologies, monetary units }\end{array}$ \\
\hline
\end{tabular}

Effects of $C \boldsymbol{C}(U) S$ projects on society. Taking into account the specific nature of $\mathrm{CO}_{2}$ sequestration and use projects and possible public opposition to such projects, their environmental and social orientation is important, as well as their role in shaping the environmental consciousness of society. This determines the need to use completely different approaches in their assessment, aimed at identifying and measuring, including sustainable social effects, which, in turn, may lead to a reassessment of the value of such initiatives. The work revealed the potential positive and negative impact of $\mathrm{CC}(\mathrm{U}) \mathrm{S}$ technologies in such areas as society and economy, safety and health, environment, and long-term environmentally-oriented development (Table 2).

Such system demonstrates the influence of both short-term and long-term (strategic) nature, which, in its turn, determines the emergence of positive and negative effects. Obviously, the goal is to increase the positive and decrease the negative influence.

For estimation can be used the proposed indicators which are divided into groups of maximization and minimization. The higher value of the first group of them and the lower value of the second one affirm a cumulative increase in social effects.

It should be noted that the presented indicators should be considered in direct connection with the $\mathrm{CC}(\mathrm{U}) \mathrm{S}$ projects. Thus, the volume of social investments, measured in monetary terms, should contain only those investments that are associated with initiation, development and implementation of the $\mathrm{CC}(\mathrm{U}) \mathrm{S}$ project. Also, many indicators (e.g., the amount of $\mathrm{CO}_{2}$ emissions, the level of public awareness of $C C(U) S$ technologies) can only be informative when examining them in dynamics. Further research will develop a full-fledged methodology for evaluating the public effectiveness of such projects with the development of recommendations for evaluating CCS, CCUS, and CCU projects.

Conclusions. The research led to the following results:

1. The essence of technologies is described and a typology of $\mathrm{CC}(\mathrm{U}) \mathrm{S}$ projects is presented, depending on which stages of the technological chain are present in them. The novelty of the obtained results lies in clear typologization of projects and analysis of their features. There is no uniform approach to the used terminology in the existing literature; many authors generalize the projects under consideration without highlighting their features, and use the general term CCS projects. 
2. A strategic analysis of the prospects for $\mathrm{CC}(\mathrm{U}) \mathrm{S}$ projects in Russia was carried out, which made it possible to identify the main strengths and weaknesses, as well as opportunities and threats of their development. The novelty of the result is in the application of SWOT-analysis for the conditions of Russia, which made it possible to systematize available information and draw a conclusion about the possibility of implementation of the projects under consideration.

3. Potential social effects of $\mathrm{CC}(\mathrm{U}) \mathrm{S}$ projects in such areas as society and economy, safety and health, environment, eco-friendly development, with a set of indicators for their evaluation have been identified. The system of indicators for assessing social effects will expand the approaches to evaluating such projects and strengthen incentives for their initiation and development, which determines the practical importance of the work. In foreign literature, the study of social effects from the implementation of CC(U)S projects has been carried out (for example, [17]), but only in a descriptive form, without highlighting the lines of their occurrence and specific indicators for evaluation. At the same time, due to the different nature of the presented indicators, their different orientation, as well as the complexity of collecting information for further calculation, it is necessary to develop and substantiate the methodology and detailed recommendations for the assessment.

The research results are long-term and can be used by government agencies and industrial companies engaged in sustainable development and, in particular, decarbonization, when initiating, planning and implementing the first $\mathrm{CO}_{2}$ sequestration projects in Russia. The results obtained can form the basis for developing an academic discussion platform on the economics of $\mathrm{CO}_{2}$ sequestration in Russia.

Further research directions are related to substantiation of the methodology for assessing the social effectiveness of $\mathrm{CC}(\mathrm{U}) \mathrm{S}$ projects with the development and consideration of the system of interests of different stakeholder groups.

\section{REFERENCES}

1. S.A.Pereverzeva, P.K.Konosavskii, A.V.Tudvachev, I.L.Kharkhordin Disposal of industrial carbon dioxide emissions into geological structures. Vestnik Sankt-Peterburgskogo universiteta. 2014. Ser. 7. Iss. 1, p. 5-17 (in Russian).

2. Karkashadze G.G., Kharin Yu.V. Modern approaches to technologies for storage of carbon dioxide in coal seams and rock masses. Gornyi informatsionno-analiticheskii byulleten. 2007. S 13. N 1, p. 291-306 (in Russian).

3. Lavrenchenko G.K., Kopytin A.V. Prospects for the improvement and widespread use of CCS technologies. Tekhnicheskie gazy. 2015. N 2, p. 3-15 (in Russian).

4. National Inventory Report of anthropogenic emissions by sources and removals by sinks of greenhouse gases not controlled by the Montreal Protocol for 1990-2017. Moscow, 2019, p. 471 (in Russian).

5. Sidorova K.I. Development of a feasibility study for $\mathrm{CO}_{2}$ capture for the energy sector. Ekologiya i promyshlennost Rossii. 2014. N 12, p. 20-25 (in Russian).

6. Fedoseev S.V., Tsvetkov P.S. Key Factors of Public Perception of Carbon Dioxide Capture and Storage Projects. Journal of Mining Institute. 2019. Vol. 237, p. 361-368. DOI: 10.31897/PMI.2019.3.361

7. Cherepovitsyn A.E., Vasilev Yu.N., Tsvetkova A.Yu. Assessment of the prospects for introducing $\mathrm{CO}_{2}$ sequestration technologies. Risk: resursy, informatsiya, snabzhenie, konkurentsiya. 2018. N 2, p. 86-89 (in Russian).

8. Cherepovitsyn A.E., Ilinova A.A., Evseeva O.O. Stakeholders management of carbon sequestration project in the state business - society system. Journal of Mining Institute. 2019. Vol. 240, p. 731-742. DOI: 10.31897/PMI.2019.6.731

9. Cherepovitsyn A.E. Economic and social aspects of the development of $\mathrm{CO}_{2}$ capture and storage technologies in the oil and gas complex of Russia. Journal of Mining Institute. 2015. Vol. 211, p. 125-130 (in Russian).

10. A Guide to the Project Management Body of Knowledge. 5th ed. Project Management Institute. USA, 2013, p. 616.

11. Burton E., Ezzedine S., Reed J., Beyer J. Accelerating Carbon Capture and Sequestration Projects: Analysis and Comparison of Policy Approaches. Energy Procedia. 2011. Vol. 4, p. 5778-5785. DOI: 10.1016/j.egypro.2011.02.574

12. BP: Statistical Review of World Energy - 2019 edition. URL: https://nangs.org/analytics/bp-statistical-review-of-worldenergy (date of access: 12.02.2020)

13. Krahe M., Heidug W., Ward J., Smale R. From demonstration to deployment: An economic analysis of support policies for carbon capture and storage. Energy Policy. 2013. Vol. 60, p. 753-763. DOI: 10.1016/j.enpol.2013.05.019

14. Henriksen D., Ombudstvedt I. CCS - What Does it Take? Necessary Framework to Succeed with CCS. Energy Procedia. 2014. Vol. 63, p. 6730-6737. DOI: 10.1016/j.egypro.2014.11.708

15. Ilinova A., Cherepovitsyn A., Evseeva O. Stakeholder Management: An Approach in CCS Projects. Resources. 2018. Vol. 7(4). N 83. DOI: 10.3390/resources7040083

16. Kapetaki Z., Scowcroft J. Overview of Carbon Capture and Storage (CCS) Demonstration Project Business Models: Risks and Enablers on the Two Sides of the Atlantic. Energy Procedia. 2017. Vol. 114, p. 6623-6630. DOI: $10.1016 /$ j.egypro.2017.03.1816 
17. Karayannis V., Charalampides G., Lakioti E. Socio-economic Aspects of CCS Technologies. Procedia Economics and Finance. 2014. Vol. 14, p. 295-302. DOI: 10.1016/S2212-5671(14)00716-3

18. Li Q., Wei Y-N, Chen Z-A. Water-CCUS Nexus: Challenges and Opportunities of China's Coal Chemical Industry. Clean Technologies and Environmental Policy. 2016. Vol. 18, p. 775-786. DOI: 10.1016/j.jclepro.2014.09.07

19. Cherepovitsyn A., Fedoseev S., Tcvetkov P., Sidorova K., Kraslawski A. Potential of Russian Regions to Implement $\mathrm{CO}_{2}$-Enhanced Oil Recovery. Energies. 2018. Vol. 11(6). 1528. DOI: 10.3390/en11061528

20. Putting $\mathrm{CO}_{2}$ to Use Creating value from emissions / Technology report. September 2019. URL:https://www.iea.org/ reports/putting-co2-to-use (date of access: 20.02.2020)

21. Romasheva N., Ilinova A. CCS Projects: How Regulatory Framework Influences Their Deployment. Resources. 2019. Vol. 8(4). N 181. DOI: 10.3390/resources8040181

22. Sander van Egmond, Hekkert M.P. Argument map for carbon capture and storage. International Journal of Greenhouse Gas Control. 2012. Vol. 11, p. 148-159. DOI: 10.1016/j.ijggc.2012.08.010

23. Singha P., Haines M. A Review of Existing Carbon Capture and Storage Cluster Projects and Future Opportunities. Energy Procedia. 2014. Vol. 63, p. 7247-7260.

24. Shabalov M.Y., Filatova I.I., Kuskova Y.V. Prospects of binary energy generation systems based on the joint use of traditional sources of energy and wave motion energy. IOP Conference Series: Materials Science and Engineering. 2019. Vol. 643. N 012143. DOI: 10.1088/1757-899X1643/1/012143

25. Lipponen J., McCulloch S., Keeling S., Stanley T., Berghout N., Berly T. The Politics of Large-scale CCS Deployment. Energy Procedia. 2017. Vol. 114, p. 7581-7595. DOI: 10.1016/j.egypro.2017.03.1890

26. Tcvetkov P., Cherepovitsyn A., Fedoseev S. The Changing Role of $\mathrm{CO}_{2}$ in the Transition to a Circular Economy: Review of Carbon Sequestration Projects. Sustainability. 2019. Vol. 11(20). N 5834. DOI: 10.3390/su11205834

27. Vasilev Y., Vasileva P., Tsvetkova A. International review of public perception of CCS technologies. 19th International Multidisciplinary Scientific Geo Conference SGEM. 2019. Vol. 19. Iss. 5.1, p. 415-422. DOI: 10.5593/sgem2019/5.1/ S20.052

28. Viebahn P., Chappin E.J.L. Scrutinising the Gap between the Expected and Actual Deployment of Carbon Capture and Storage - A Bibliometric Analysis. Energies. 2018. Vol. 11. N 2319. DOI: https://doi.org/10.3390/en11092319

29. Viebahn P., Vallentin D., Höller S. Integrated Assessment of Carbon Capture and Storage (CCS) in South Africa's Power Sector. Energies. 2015. Vol. 8, p. 14380-14406.

30. Zhao X., Yin H., Zhao Y. Impact of environmental regulations on the efficiency and $\mathrm{CO}_{2}$ emissions of power plants in China. Applied Energy. 2015. Vol. 149, p. 238-247. DOI: 10.1016/j.apenergy.2015.03.112

Authors: Alina A. Ilinova, Candidate of Economics, Associate Professor, iljinovaaa@mail.ru (Saint Petersburg Mining University, Saint Petersburg, Russia), Natalya V. Romasheva, Candidate of Economics, Associate Professor, natasmir84@mail.ru (Saint Petersburg Mining University, Saint Petersburg, Russia), Gennadiy A. Stroykov, Candidate of Economics, Assistant Lecturer, g.a.stroykov@mail.ru (Saint Petersburg Mining University, Saint Petersburg, Russia).

The paper was received on 20 February, 2020.

The paper was accepted for publication on 16 July, 2020. 